\title{
PENGEMBANGAN MODUL PRAKTIKUM BERBASIS MULTIMEDIA INTERAKTIF PADA PRAKTIKUM ELEKTRONIKA DASAR I MATERI DIODA II MAHASISWA PENDIDIKAN FISIKA UIN WALISONGO TAHUN 2015
}

\author{
M. Najib Mustaqim ${ }^{1}$, Wenty Dwi Yuniarti, S.Pd, M. Kom², \\ Agus Sudarmanto, M.Si ${ }^{3}$ \\ Program Studi Pendidikan Fisika Fakultas Sains dan Teknologi \\ UIN Walsiongo \\ Email : mustaqim_physics@yahoo.com, wenty@walisongo.ac.id, agussudarmanto@walisongo.ac.id
}

\begin{abstract}
ABSTRAK
Modul praktikum merupakan bentuk bahan ajar yang digunakan mahasiswa sebagai panduan dalambelajar praktikum secara mandiri.Modul belum sepenuhnya memudahkan mahasiswa dalam mengerjakan praktikumdanditemukan kesalahan memahami prosedur kerja, terutama pada modul Praktikum Elektronika Dasar I materi Dioda II(sebagai penyearah). Oleh karena itu peneliti mengembangkan modul berbasis multimedia interaktif yang memberi gambaran Praktikum Elektronika Dasar I Materi Dioda II.

Penelitian ini merupakan penelitian R \& D (Research and Development) dengan prosedur pengembangan yaitu (1) Analisis kebutuhan, (2) Perancangan, (3) Pembuatan, (4) Pengujian, (5) Pengoperasian dan Pemeliharaan. Subjek dalam penelitian ini adalah 20 mahasiswa pra-penelitian, 4 Dosen penilai, 2 mahasiswa uji terbatas dan 13 mahasiswa uji luas. Teknik pengumpulan data menggunakan teknik observasi, dokumentasi,dan angket. Teknik analisis data yang digunakan menggunakan deskriptif kualitatif dan kuantitatif.

Hasil penelitian Pengembangan Modul Praktikum BerbasisMultimedia Interaktif pada Praktikum Elektronika Dasar I Materi Dioda II Mahasiswa Pendidikan Fisika UIN Walisongo Tahun 2015 diperoleh nilai rata-rata hasil uji keseluruhan 3,59 dan persentase keidealan 83\% dengan rincian dari uji ahli bahan ajar sebesar 3,92 dan persentase keidealan 78\%, dari uji ahli media sebesar 3,71 dan persentase keidealan $75 \%$, dari dosen pengampu praktikum sebesar 3,72 dan persentase keidealan 94\%, dari uji lapangan terbatas sebesar 3,30 dan persentase keidealan 83\% dan dari uji lapangan luas sebesar 3,32 dengan persentase keidealan $83 \%$. Dari data tersebut maka modul praktikum berbasis multimedia interaktif sangat baik digunakan mahasiswa sebagai panduan dalam melaksanakan praktikum.
\end{abstract}

Kata kunci : pengembangan modul praktikum, multimedia interaktif, dioda 2

\section{PENDAHULUAN}

Praktikum pada program studi Pendidikan Fisika UIN Walisongo Semarang dimulai dari semester I sampai dengan semester VII, yang meliputi Praktikum Fisika Dasar I, Fisika Dasar II, Elekronika Dasar I, Elektronika Dasar II, Optika dan Gelombang, Prakarya Fsika, Pemrograman Komputer, Simulasi dan Pemodelan Fisika. Praktikum Elektronika Dasar merupakan implementasi praktik untuk menerapkan teori yang sudah dipelajari dalam mata kuliah 
Elektonika Dasar. Praktikum dapat membuat mahasiswa bertambah dan berkembang ilmunya jika praktikum dilaksanakan dengan baik (Acep Musliman, 2012). Praktikum Elektronika Dasar I di Pendidikan Fisika UIN Walisongo Semarang merupakan implementasi praktikdari mata kuliah Elektonika Dasar I dengan bobot 2 sks yang wajib diambil oleh mahasiswa dan dilaksanakan pada semester gasal. Praktikum dilaksanakan mahasiswa secara mandiri terbimbing.

Modul merupakan salah satu bentuk bahan ajar yang disusun secara sistematis menggunakan bahasa yang mudah dipahami, sesuai tingkat pengetahuan dan usia peserta didik agar dapat belajar sendiri (Andi, Prastowo, 2014). Modul praktikum yang digunakan sebagai panduan melaksanakan praktikum, diharapkan membantu mahasiswa praktikan melaksanakan tugasnya secara mandiri. Fleksibilitas modul sebagai bahan pembelajaran sangat tinggi maka, setiap modul dapat dikembangkan untuk memenuhi kebutuhan peningkatan kompetensi dari mahasiswa (Daryanto, 2013).

Berdasarkan observasi yang dilakukan pada bulan Juni 2015 dengan menyebarkan angket kepada mahasiswa Pendidikan Fisika angkatan 2013 didapatkan mahasiswa masih mengalami kesulitan dalam memahami prosedur kerja yang ada di dalam modul. Mahasiswa masih sering melakukan kesalahan merakitrangkaian dengan panduan gambar dan belum mengetahui terhadap hasil akhir dari rangkaian yang dirakit. Khususnya dalam mengerjakan praktikum materi Dioda II (Dioda sebagai penyearah), karena dalam materi ini dibutuhkan ketelitian dari mahasiswa dalam merakit rangkaian. Ditemukannya permasalahan di atas muncul suatu inovasi untuk membuat modul animasi dan simulasi guna mengurangi kekurangan dalam pelaksanaan praktikum. Sehingga perlu pengembangan Modul Praktikum berbasis Multimedia Interaktif dengan Adobe Flash Cs 6 dan Proteus 8 pada Praktikum Elektronika Dasar I Materi Dioda II Mahasiswa Pendidikan Fisika UIN Walisongo.

\section{METODE PENELITIAN}

Pada penelitian ini peneliti menggunakan model pengembangan secara prosedural yang bersifat deskriptif dan menunjukkan langkah-langkah yang harus diikuti untuk menghasilkan produk meliputi : analisis kebutuhan, perancangan produk, pembuatan produk, pengujian produk, pengoperasian dan pemeliharaan. 
Teknik Pengumpulan Data : Observasi (peneliti terlibat dalam kegiatan Praktikum Elektronika Dasar I), Dokumentasi (angket dari penilaian ahli, angket dari mahasiswa praktikan, data hasil praktikum dan foto kegiatan praktikum), Angket (angket dengan skala likert serta lembar kritik dan saran guna mengetahui kualitas modul Praktikum Elektronika Dasar I untuk Dosen pengampu praktikum, Dosen ahli bahan ajar, dan Dosen ahli media).

Teknik Analisis Data : Data kualitatif dalam penelitian ini berupa kategori nilai kualitas modul praktikum dan data kuantitatif dalam penelitian ini berupa skor penilaian setiap indikator dengan 4 kriteria penilaian yang dilakukan oleh para ahli dan Dosen pengampu Praktikum Elektronika Dasar I pada lembar penilaian kualitas modul praktikum.

\section{HASIL DAN PEMBAHASAN}

\section{Analisis Kebutuhan dan Desain Produk}

Sebelum melakukan sebuah penelitian, dilakukan analisis kebutuhan mengidentifikasi masalah mendasar yang dibutuhkan dalam pengembangan modul. Analisis kebutuhan ini berangkat dari pengalaman Praktikum Elektronika Dasar dari peneliti yang mengalami kesulitan dalam praktikum. Dari penyebaran angket diperoleh data rata-rata 2,4 dengan 6 item pertanyaan yang menggunakan skala likert dengan 4 kriteria sebagai berikut sangat setuju $=4$, setuju $=3$, kurang setuju $=2$, tidak setuju $=1$, dan diperoleh persentase keidealan modul adalah $60 \%$ dengan kategori kurang. Hasil analisis kebutuhan dalam bentuk grafik dapat dilihat pada gambar 1 .

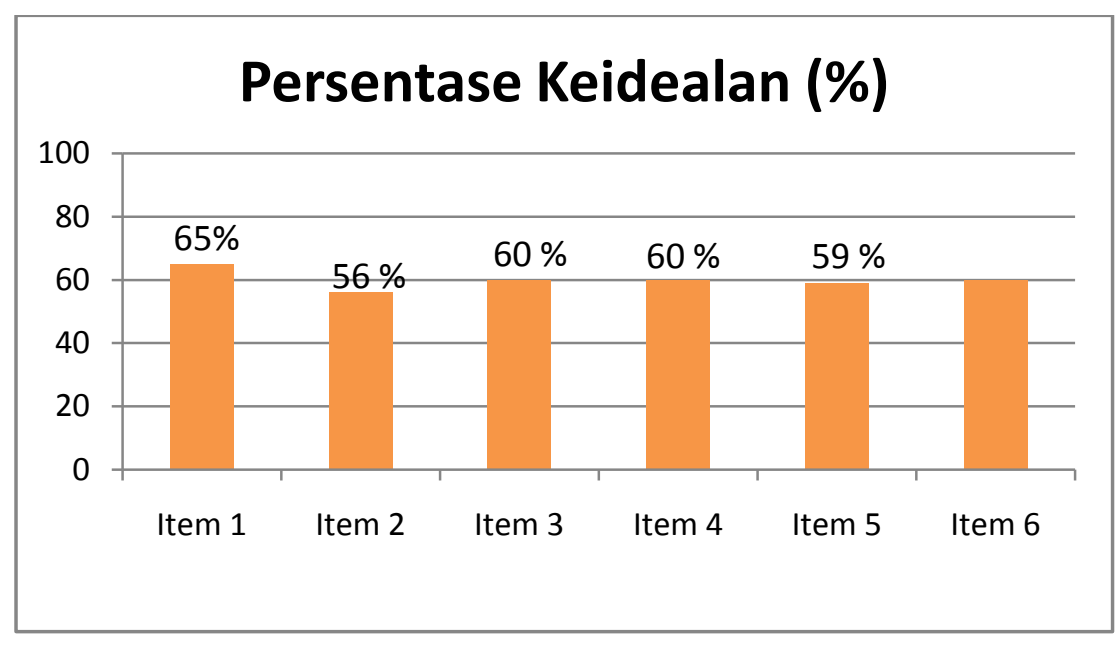

Gambar 1. Grafik hasil analisis kebutuhan 
Hasil penyebaran angket kepada 20 mahasiswa angkatan 2013 didapatkan data seperti pada tabel 4.1, dimana mahasiswa masih mengalami kesulitan dalam memahami modul praktikum yang ada, hal itu dibuktikan dari statistik yang menunjukkan angka di bawah kategori baik yaitu pada nilai 2,41 dengan persentase kelayakan sebesar 60\% dengan kategori kurang (K).

Maka dikembangkan modul berbasis multimedia interaktrif yang dapat memudahkan mahasiswa dalam memahami modul praktikum, karena modul ini sepenuhnya dalam kendali pengguna, maka pengguna dapat mengatur nilai-nilai komponen elektronika yang dikehendaki. Seperti mengatur nilai tegangan powersupply, dioda, kapasitor, dan komponen yang lain. Modul ini memiliki bagian-bagian sebagai berikut :

1. Tampilan awal (halaman $\log$ in)
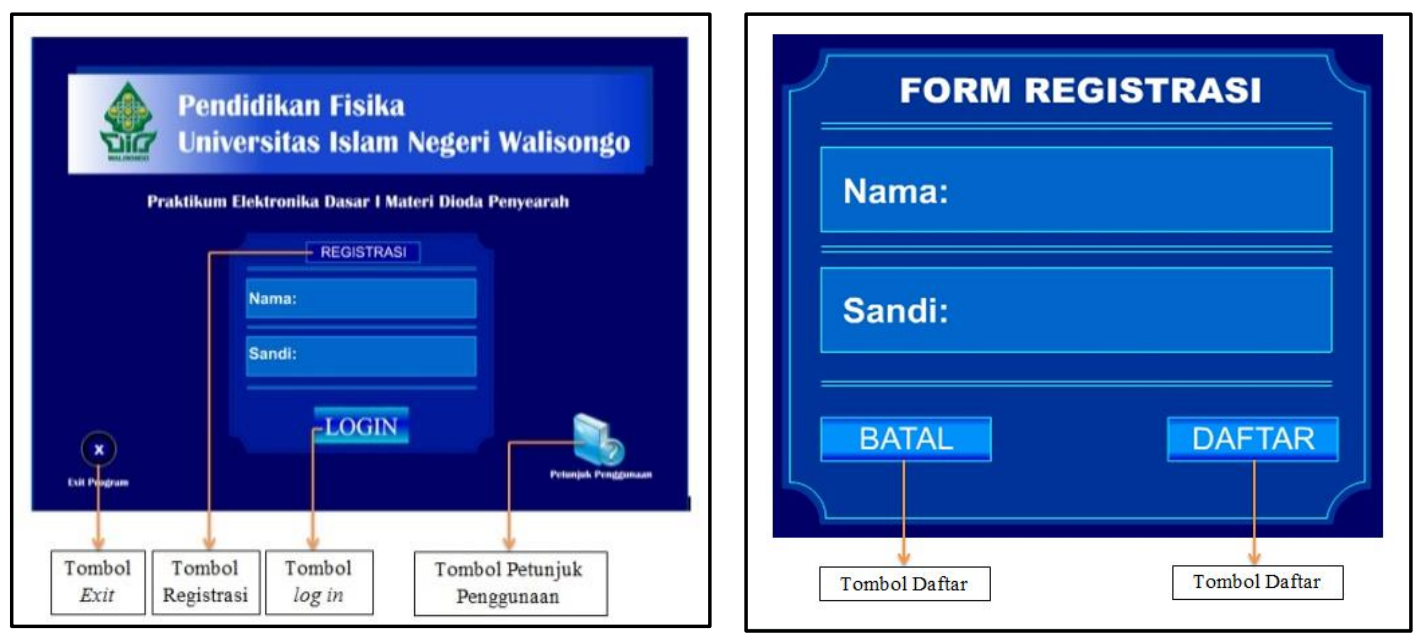

Gambar 2. Tampilan awal dan form registrasi modul multimedia interaktif

2. Tampilan Pembuka (halaman selamat datang) dan utama (home)
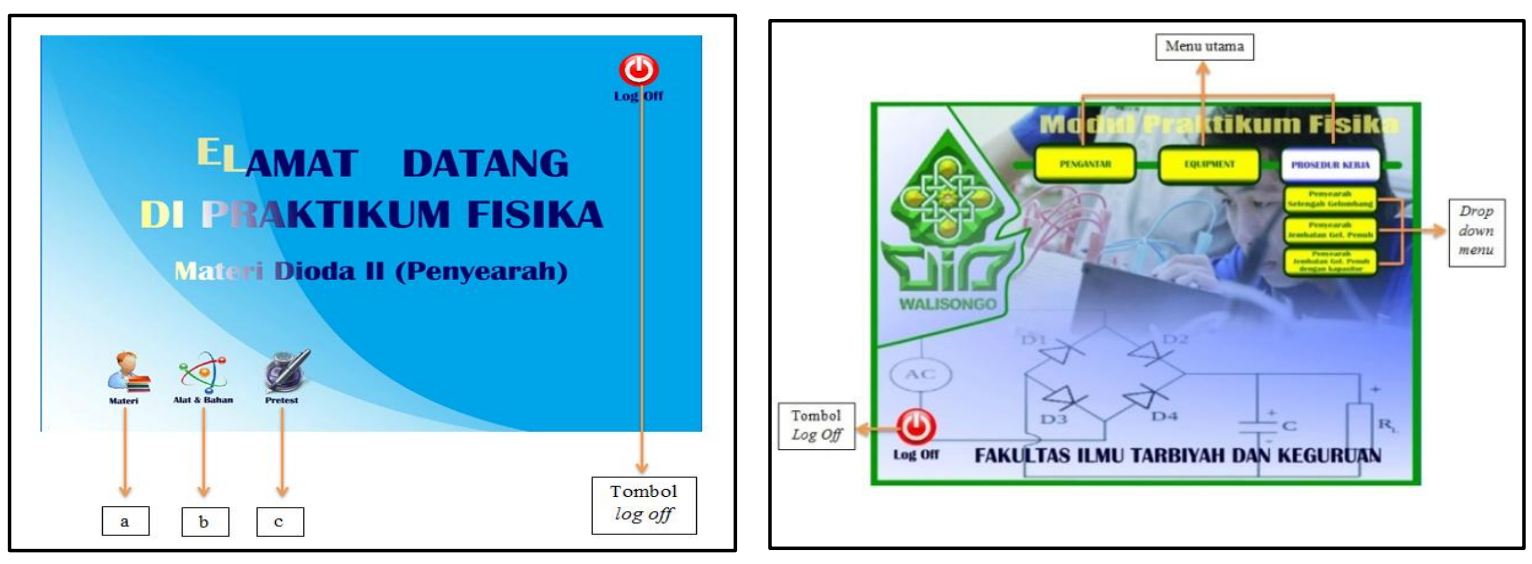

Gambar 3. Tampilan pembuka dan utama (home) 
3. Tampilan prosedur kerja dan simulasi proteus
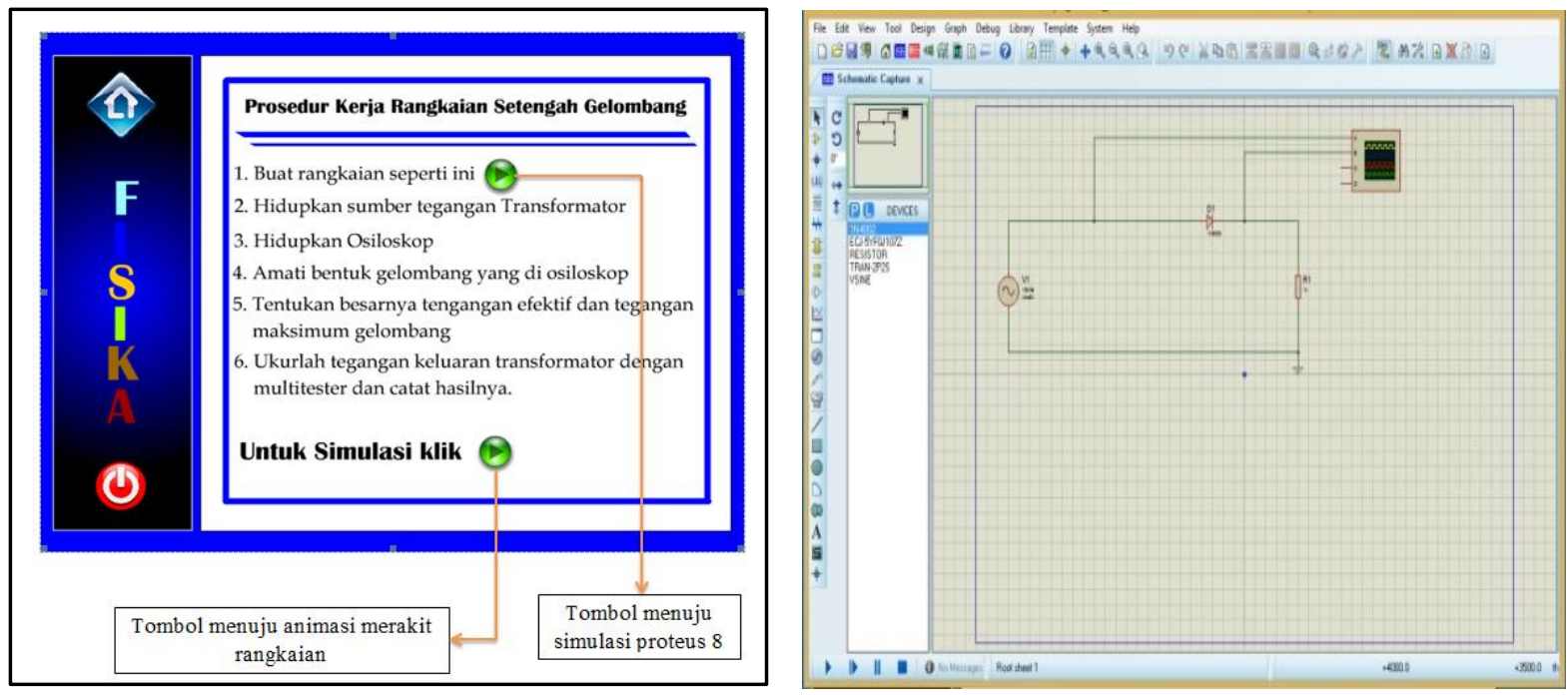

Gambar 4. Tampilan prosedur kerja dan simulasi proteus

4. Tampilan alat bahan dan dasar teori
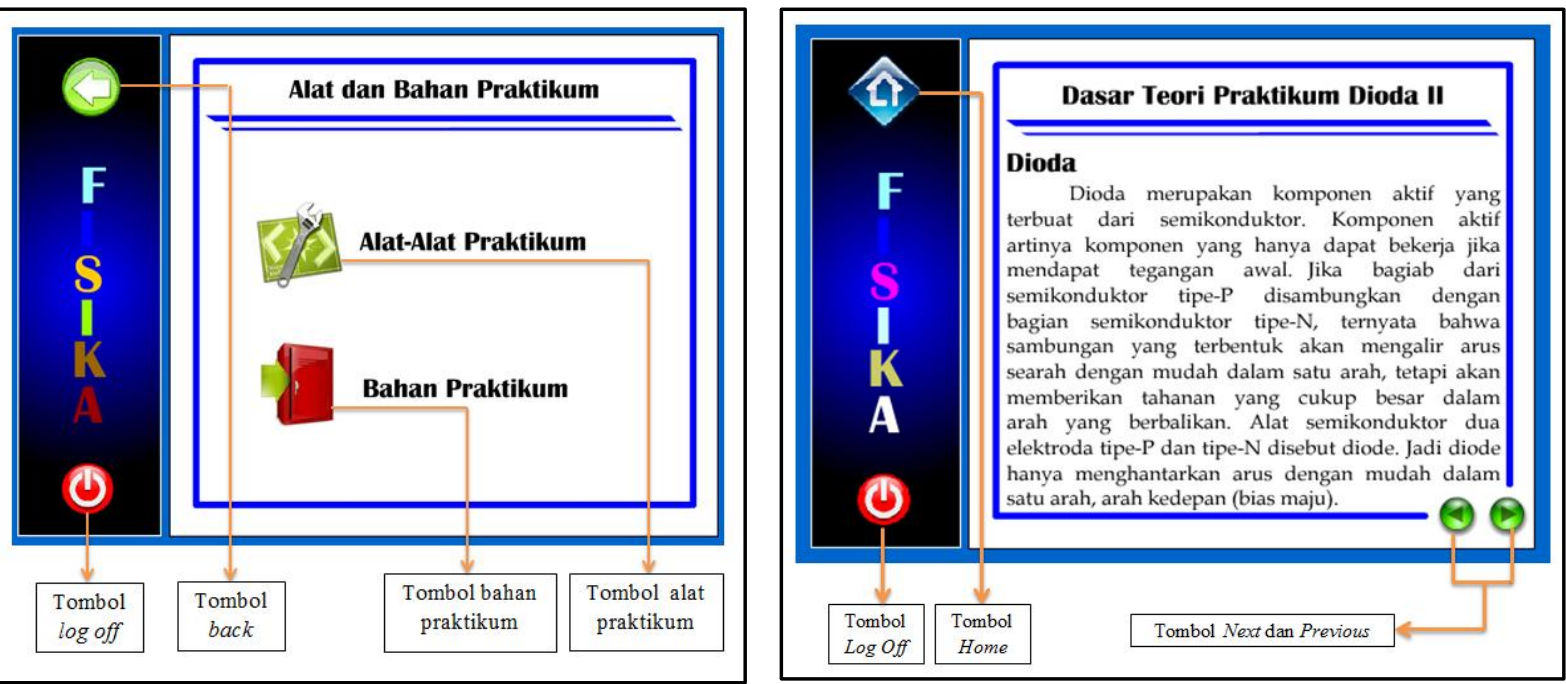

Gambar 5. Tampilan alat bahan dan dasar teori 
5. Tampilan rangkaian dioda penyearah

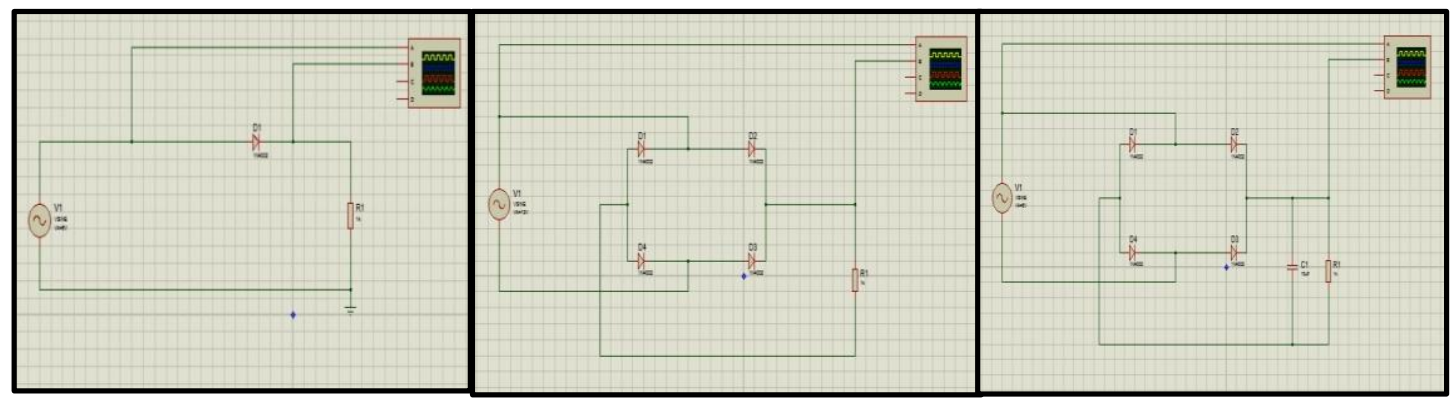

Gambar 5. Tampilan Rangkaian dioda penyearah setengah gelombang, gelombang penuh dan dengan filter kapasitor

6. Tampilan simulasi

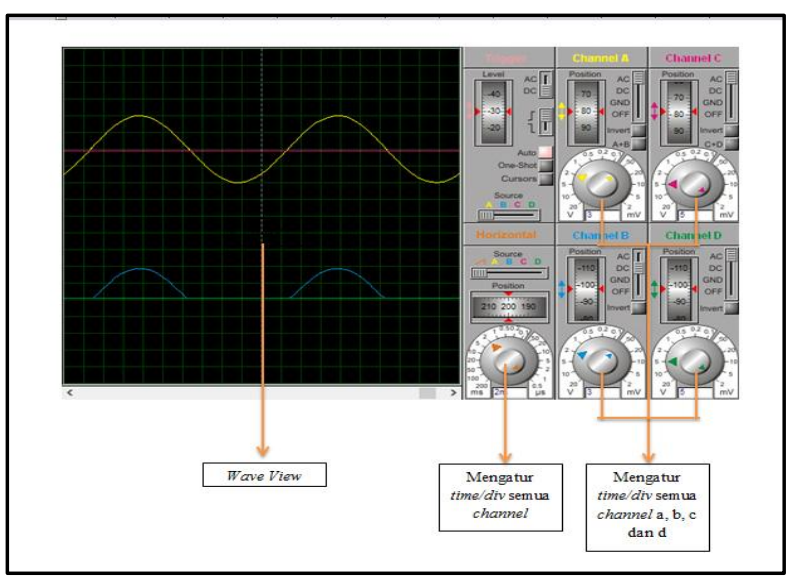

Gambar 5. Tampilan simulasi osiloskop

\section{Uji Produk}

Uji produk dilakukan untuk mendapatkan kualitas modul yang di kembangkan. Namun sebelum di ujicobakan, modul di validasi oleh validator. Validasi produk diberikan kepada Ibu Wenty Dwi Yuniarti, S.Pd., M.Kom sebagai validasi I dalam bidang Adobe Flash Cs 6 dan Bapak Agus Sudarmanto, M.Si., sebagai validator II dalam bidang Proteus 8. Setelah mendapatkan masukan dari validator I dan Validator II maka dilakukan perbaikan terhadap modul berbasis multimedia interaktif, sehingga modul layak untuk diuji ahli. 


\section{Uji Ahli}

Setelah modul mendapat persetujuan dari validator, maka modul diuji kualitasnya oleh 2 Dosen ahli yaitu Bapak Andi Fadlan, S.Si., M.Sc. sebagai Dosen ahli bahan ajar, Bapak M. Ardhi Khalif, M.Sc sebagai Dosen ahli media.

Berikut hasil penilaian oleh Dosen ahli bahan ajar dan media terhadap modul Praktikum Elektronika Dasar I berbasis multimedia interaktif seperti pada Tabel 1.

Tabel 1. Hasil penilaian oleh Dosen ahli bahan ajar

\begin{tabular}{|c|c|c|c|c|c|c|}
\hline Dosen Ahli Bahan Ajar & Aspek & No. Aspek & Nilai & $\Sigma$ & $\bar{X}$ & $\%$ \\
\hline \multirow{21}{*}{ Andi Fadlan, S.Si., M.Sc., } & \multirow{3}{*}{ Bahasa } & 1 & 5 & \multirow{3}{*}{11} & \multirow{3}{*}{3,667} & \multirow{3}{*}{$73 \%$} \\
\hline & & 2 & 2 & & & \\
\hline & & 3 & 4 & & & \\
\hline & \multirow{11}{*}{ Isi/Konten } & 1 & 5 & \multirow{11}{*}{47} & \multirow{11}{*}{4,273} & \multirow{11}{*}{$85 \%$} \\
\hline & & 2 & 4 & & & \\
\hline & & 3 & 4 & & & \\
\hline & & 4 & 5 & & & \\
\hline & & 5 & 2 & & & \\
\hline & & 6 & 4 & & & \\
\hline & & 7 & 4 & & & \\
\hline & & 8 & 5 & & & \\
\hline & & 9 & 5 & & & \\
\hline & & 10 & 4 & & & \\
\hline & & 11 & 5 & & & \\
\hline & \multirow{3}{*}{ Tampilan } & 1 & 4 & \multirow{3}{*}{12} & \multirow{3}{*}{4} & \multirow{3}{*}{$80 \%$} \\
\hline & & 2 & 4 & & & \\
\hline & & 3 & 4 & & & \\
\hline & \multirow{4}{*}{ Media Keseluruhan } & 1 & 4 & \multirow{4}{*}{15} & \multirow{4}{*}{3,75} & \multirow{4}{*}{$75 \%$} \\
\hline & & 2 & 2 & & & \\
\hline & & 3 & 5 & & & \\
\hline & & 4 & 4 & & & \\
\hline$\Sigma$ keseluruhan & \multicolumn{6}{|c|}{85} \\
\hline $\bar{X}$ Keseluruhan & \multicolumn{6}{|c|}{3,922348485} \\
\hline$\%$ Kelayakan & \multicolumn{6}{|c|}{$78 \%$} \\
\hline
\end{tabular}

Secara kesuluruhan penilaian oleh ahli bahan ajar mendapatkan nilai 3,92 dengan persentase kelayakan sebesar 78\%. Dengan demikian menurut ahli bahan ajar modul Praktikum Elektronika Dasar I berbasis multimedia interaktif dikategorikan baik (B). 
Tabel 2. Hasil penilaian Oleh Dosen ahli media

\begin{tabular}{|c|c|c|c|c|c|c|}
\hline Dosen Ahli Media & Aspek & No. Aspek & Nilai & $\Sigma$ & $\bar{X}$ & $\%$ \\
\hline \multirow{25}{*}{ M. Ardhi Khalif, M.Sc. } & \multirow{8}{*}{ Tampilan } & 1 & 4 & \multirow{8}{*}{33} & \multirow{8}{*}{4,13} & \multirow{8}{*}{$83 \%$} \\
\hline & & 2 & 5 & & & \\
\hline & & 3 & 5 & & & \\
\hline & & 4 & 5 & & & \\
\hline & & 5 & 3 & & & \\
\hline & & 6 & 4 & & & \\
\hline & & 7 & 3 & & & \\
\hline & & 8 & 4 & & & \\
\hline & \multirow{11}{*}{ Isi/Konten } & 1 & 4 & \multirow{11}{*}{44} & \multirow{11}{*}{4} & \multirow{11}{*}{$80 \%$} \\
\hline & & 2 & 4 & & & \\
\hline & & 3 & 4 & & & \\
\hline & & 4 & 4 & & & \\
\hline & & 5 & 4 & & & \\
\hline & & 6 & 4 & & & \\
\hline & & 7 & 4 & & & \\
\hline & & 8 & 4 & & & \\
\hline & & 9 & 4 & & & \\
\hline & & 10 & 4 & & & \\
\hline & & 11 & 4 & & & \\
\hline & \multirow{2}{*}{ Bahasa } & 1 & 3 & \multirow{2}{*}{6} & \multirow{2}{*}{3} & \multirow{2}{*}{$60 \%$} \\
\hline & & 2 & 3 & & & \\
\hline & \multirow{4}{*}{ Media Keseluruhan } & 1 & 3 & \multirow{4}{*}{15} & \multirow{4}{*}{3,75} & \multirow{4}{*}{$75 \%$} \\
\hline & & 2 & 4 & & & \\
\hline & & 3 & 4 & & & \\
\hline & & 4 & 4 & & & \\
\hline$\Sigma$ keseluruhan & \multicolumn{6}{|c|}{98} \\
\hline $\bar{X}$ Keseluruhan & \multicolumn{6}{|c|}{3,71875} \\
\hline$\%$ Kelayakan & \multicolumn{6}{|c|}{$74 \%$} \\
\hline
\end{tabular}

Secara kesuluruhan penilaian oleh ahli media mendapatkan nilai 3,71 dengan persentase kelayakan sebesar 74\%. Dengan demikian menurut ahli bahan ajar modul Praktikum Elektronika Dasar I berbasis multimedia interaktif dikategorikan baik (B). Dari hasil penilaian ahli materi dan ahli media maka maodul layak untuk di uji lapangan secara terbatas dan luas.

\section{Uji Lapangan Terbatas dan Luas}

Uji lapangan terbatas dilakukan pada mahasiswa semester 3 angkatan 2014 A sejumlah 1 kelompok yang terdiri dari 2 mahasiswa dan tercatat dalam daftar hadir perkuliahan Praktikum Elektronika Dasar I tahun 2015. Berikut data hasil uji lapangan terbatas respon mahasiswa terhadap modul Praktikum Elektronika Dasar I berbasis multimedia interaktif seperti Tabel 3. 
Tabel 3. Hasil uji lapangan terbatas

\begin{tabular}{|c|c|c|c|c|c|c|c|}
\hline Nama Mahasiswa & Aspek & No. Aspek & Nilai I & Nilai II & $\Sigma$ & $\bar{X}$ & $\%$ \\
\hline \multirow{2}{*}{ Mahasiswa I } & \multirow{6}{*}{ Tampilan } & 1 & 3 & 3 & \multirow{6}{*}{37} & \multirow{6}{*}{3,08} & \multirow{6}{*}{$77 \%$} \\
\hline & & 2 & 2 & 3 & & & \\
\hline \multirow{10}{*}{ Yuni Zulaekha } & & 3 & 3 & 3 & & & \\
\hline & & 4 & 3 & 3 & & & \\
\hline & & 5 & 3 & 3 & & & \\
\hline & & 6 & 4 & 4 & & & \\
\hline & \multirow{12}{*}{ Isi/Konten } & 1 & 4 & 3 & \multirow{12}{*}{83} & \multirow{12}{*}{3,46} & \multirow{12}{*}{$86 \%$} \\
\hline & & 2 & 4 & 4 & & & \\
\hline & & 3 & 4 & 3 & & & \\
\hline & & 4 & 3 & 3 & & & \\
\hline & & 5 & 3 & 3 & & & \\
\hline & & 6 & 3 & 4 & & & \\
\hline \multirow{2}{*}{ Mahasiswa II } & & 7 & 4 & 4 & & & \\
\hline & & 8 & 4 & 4 & & & \\
\hline \multirow{13}{*}{ Muhammad Asror } & & 9 & 4 & 4 & & & \\
\hline & & 10 & 4 & 3 & & & \\
\hline & & 11 & 3 & 3 & & & \\
\hline & & 12 & 3 & 2 & & & \\
\hline & \multirow{3}{*}{ Bahasa } & 1 & 4 & 3 & \multirow{3}{*}{21} & \multirow{3}{*}{3,5} & \multirow{3}{*}{$88 \%$} \\
\hline & & 2 & 4 & 3 & & & \\
\hline & & 3 & 4 & 3 & & & \\
\hline & \multirow{6}{*}{ Media Keseluruhan } & 1 & 4 & 2 & \multirow{6}{*}{39} & \multirow{6}{*}{3,25} & \multirow{6}{*}{$81 \%$} \\
\hline & & 2 & 4 & 3 & & & \\
\hline & & 3 & 4 & 3 & & & \\
\hline & & 4 & 4 & 2 & & & \\
\hline & & 5 & 4 & 3 & & & \\
\hline & & 6 & 4 & 2 & & & \\
\hline$\Sigma$ keseluruhan & \multicolumn{7}{|c|}{180} \\
\hline $\bar{X}$ Keseluruhan & \multicolumn{7}{|c|}{3,333333333} \\
\hline \% Kelayakan & \multicolumn{7}{|c|}{$83 \%$} \\
\hline
\end{tabular}

Secara kesuluruhan respon mahasiswa terhadap modul multimedia interaktif mendapat nilai 3,33 dengan persentase kelayakan sebesar 83\% dengan kategori sangat baik (SB). Selain melakukan penilaian, mahasiswa sebagai calon pengguna modul juga memberikan masukan yang membangun. Masukan ini sebagai bahan perbaikan, sehingga modul yang diujikan pada tahap selanjutnya.

Uji lapangan skala luas dilakukan terhadap 3 kelompok praktikum kelas Pendidikan Fisika 2014 A dan 2 kelompok praktikum kelas Pendidikan Fisika 2014 B. Berikut data hasil uji lapangan terbatas respon mahasiswa terhadap modul Praktikum Elektronika Dasar I berbasis multimedia interaktif seperti Tabel 4. 
Tabel 4.9. Hasil uji lapangan luas

\begin{tabular}{|c|c|c|c|c|c|c|c|c|c|c|c|c|c|c|c|c|c|c|c|c|c|c|c|c|c|}
\hline \multirow{2}{*}{ No. } & \multirow{2}{*}{ Nama Mahasiswa } & \multicolumn{21}{|c|}{ Pernyataan } & \multicolumn{3}{|c|}{ Keseluruhan } \\
\hline & & \multicolumn{4}{|c|}{ Tampilan } & \multicolumn{10}{|c|}{ Isi/Konten Media } & \multicolumn{2}{|c|}{ Bahasa } & \multicolumn{5}{|c|}{ Media Keseluruhan } & \begin{tabular}{l|l}
$n$ & $\Sigma$ \\
\end{tabular} & $\bar{X}$ & $\%$ \\
\hline & Nomer Indikator & 1 & \begin{tabular}{|l|l|}
2 & 3 \\
\end{tabular} & & 6 & 1 & 2 & 3 & \begin{tabular}{l|l}
44 & 5
\end{tabular} & \begin{tabular}{|l|l}
6 & 7 \\
\end{tabular} & \begin{tabular}{|l|l|}
7 & 8 \\
\end{tabular} & 9 & 10 & 11 & 12 & 1 & \begin{tabular}{l|l}
2 & 3 \\
\end{tabular} & 1 & 2 & 3 & 455 & \begin{tabular}{l|l}
5 & 6
\end{tabular} & & & \\
\hline 1 & Anto Hidayatullah & 4 & \begin{tabular}{|l|l|}
3 & 4 \\
\end{tabular} & \begin{tabular}{l|l}
4 & 4
\end{tabular} & 4 & 4 & 4 & 3 & \begin{tabular}{l|l}
3 & 3 \\
\end{tabular} & \begin{tabular}{|l|l}
3 & 3 \\
\end{tabular} & \begin{tabular}{|l|l|}
3 & 4 \\
\end{tabular} & 4 & 4 & 3 & 4 & 4 & \begin{tabular}{l|l}
33 & 4
\end{tabular} & 4 & 3 & 3 & 45 & \begin{tabular}{l|l}
4 & 4 \\
\end{tabular} & & & \\
\hline 21 & Dina Sofiya & 3 & \begin{tabular}{l|l|}
3 & 3 \\
\end{tabular} & 33 & 3 & 3 & 3 & 3 & \begin{tabular}{l|l}
2 & 3 \\
\end{tabular} & 23 & \begin{tabular}{|l|l|}
3 & 3 \\
\end{tabular} & 3 & 3 & 2 & 3 & 3 & \begin{tabular}{l|l}
3 & 3 \\
\end{tabular} & 4 & 3 & 3 & 33 & \begin{tabular}{|l|l|}
3 & 3 \\
\end{tabular} & & & \\
\hline 3 & Fitri Kamelia & 3 & \begin{tabular}{l|l}
3 & 4 \\
\end{tabular} & $\begin{array}{ll}3 & 3 \\
\end{array}$ & 3 & 4 & 3 & 3 & $\begin{array}{lll}3 & 3 \\
\end{array}$ & 33 & \begin{tabular}{|l|l|}
3 & 4 \\
\end{tabular} & 4 & 3 & 3 & 4 & 3. & \begin{tabular}{l|l}
3 & 3 \\
\end{tabular} & 4 & 3 & 4 & 33 & $\begin{array}{lll}3 & 3 \\
\end{array}$ & & & \\
\hline 4 & Isna Juwita & 4 & \begin{tabular}{|l|l|}
4 & 4 \\
\end{tabular} & 44 & 3 & 4 & 3 & 4 & \begin{tabular}{|l|l}
4 & 4 \\
\end{tabular} & 44 & \begin{tabular}{|l|l|}
4 & 4 \\
\end{tabular} & 3 & 4 & 3 & 3 & 4 & \begin{tabular}{l|l}
4 & 4 \\
\end{tabular} & 4 & 4 & 4 & 433 & $\begin{array}{ll}3 & 3 \\
\end{array}$ & & & \\
\hline 5 & Muhammad Yusuf & 3 & \begin{tabular}{|l|l|}
3 & 4 \\
\end{tabular} & $\begin{array}{ll}3 & 3 \\
\end{array}$ & 3 & 4 & 4 & 3 & \begin{tabular}{l|l}
3 & 4 \\
\end{tabular} & 43 & \begin{tabular}{|l|l|}
3 & 3 \\
\end{tabular} & 3 & 3 & 3 & 3 & 4. & \begin{tabular}{l|l}
4 & 4 \\
\end{tabular} & 4 & 3 & 3 & 45 & \begin{tabular}{l|l}
4 & 3 \\
\end{tabular} & & & \\
\hline 6 & Nur Isrokhiiyati & 4 & \begin{tabular}{l|l|l}
4 & 3 \\
\end{tabular} & $\begin{array}{ll}3 & 3 \\
\end{array}$ & 34 & 3 & 2 & 3 & \begin{tabular}{l|l}
4 & 4 \\
\end{tabular} & 44 & \begin{tabular}{|l|l|}
4 & 4 \\
\end{tabular} & 3 & 3 & 3 & 2 & 4. & \begin{tabular}{l|l}
3 & 3 \\
\end{tabular} & 3 & 4 & 3 & 43 & \begin{tabular}{|l|l|}
3 & 4 \\
\end{tabular} & & & \\
\hline 7 & Ravena Yasnel & 3 & \begin{tabular}{l|l|}
4 & 4 \\
\end{tabular} & $\begin{array}{ll}3 & 3 \\
\end{array}$ & 34 & 4 & 4 & 3 & \begin{tabular}{l|l}
4 & 3 \\
\end{tabular} & 33 & \begin{tabular}{|l|l|}
3 & 4 \\
\end{tabular} & 4 & 4 & 4 & 4 & 4. & \begin{tabular}{l|l}
4 & 4 \\
\end{tabular} & 4 & 4 & 4 & 45 & \begin{tabular}{l|l}
4 & 4 \\
\end{tabular} & & & \\
\hline 8 & Syifa Diatmika & 3 & $\begin{array}{lll}3 & 4 \\
\end{array}$ & 33 & 3 & 4 & 4 & 4 & $\begin{array}{ll}3 & 3 \\
\end{array}$ & 33 & \begin{tabular}{ll|}
3 & 3 \\
\end{tabular} & 4 & 4 & 3 & 3 & 3 & $\begin{array}{ll}3 & 3 \\
\end{array}$ & 4 & 3 & 4 & 45 & $\begin{array}{ll}4 & 4 \\
\end{array}$ & & & \\
\hline 9 & Taffadani Adnan M & 3 & \begin{tabular}{l|l|}
3 & 3 \\
\end{tabular} & \begin{tabular}{l|l}
3 & 3 \\
\end{tabular} & 3 & 3 & 3 & 3 & \begin{tabular}{l|l}
3 & 3 \\
\end{tabular} & 33 & \begin{tabular}{|l|l|}
3 & 3 \\
\end{tabular} & 3 & 3 & 3 & 3 & 3 & \begin{tabular}{l|l}
3 & 3 \\
\end{tabular} & 3 & 3 & 3 & 33 & $\begin{array}{ll}3 & 3 \\
\end{array}$ & 1162 & 3,3 & $83 \%$ \\
\hline 10 & Ummi Nuzulul F & 2 & \begin{tabular}{|l|l|}
2 & 4 \\
\end{tabular} & $\begin{array}{l}32 \\
\end{array}$ & 4 & 4 & 3 & 3 & \begin{tabular}{l|l}
4 & 3 \\
\end{tabular} & 33 & \begin{tabular}{|l|l|}
3 & 3 \\
\end{tabular} & 3 & 4 & 2 & 3 & 2 & \begin{tabular}{l|l}
3 & 3 \\
\end{tabular} & 4 & 3 & 2 & 13 & \begin{tabular}{l|l}
3 & 2 \\
\end{tabular} & & & \\
\hline 11 & Vella SS & 3 & \begin{tabular}{l|l|}
3 & 3 \\
\end{tabular} & $\begin{array}{ll}3 & 3 \\
\end{array}$ & 3 & 3 & 3 & 3 & \begin{tabular}{l|l}
3 & 3 \\
\end{tabular} & 33 & \begin{tabular}{|l|l|}
3 & 3 \\
\end{tabular} & 3 & 3 & 3 & 3 & 3 & \begin{tabular}{l|l}
4 & 3 \\
\end{tabular} & 3 & 3 & 3 & 33 & \begin{tabular}{|l|l|}
3 & 3 \\
\end{tabular} & & & \\
\hline 12 & Widy Lestari & 4 & \begin{tabular}{|l|l|}
4 & 4 \\
\end{tabular} & $4 \sqrt{4}$ & +3 & 3 & 3 & 3 & \begin{tabular}{l|l}
3 & 3 \\
\end{tabular} & 33 & \begin{tabular}{|l|l|}
3 & 4 \\
\end{tabular} & 3 & 3 & 2 & 3 & 3 & \begin{tabular}{l|l}
3 & 3 \\
\end{tabular} & 3 & 3 & 3 & 33 & \begin{tabular}{|l|l}
3 & 3 \\
\end{tabular} & & & \\
\hline 13 & Zaidatun Masruroh & 3 & \begin{tabular}{|l|l|}
4 & 3 \\
\end{tabular} & \begin{tabular}{l|l}
3 & 4 \\
\end{tabular} & 3 & 4 & & 3 & \begin{tabular}{l|l}
3 & 3 \\
\end{tabular} & \begin{tabular}{|l|l}
3 & 3 \\
\end{tabular} & \begin{tabular}{|l|l|}
3 & 3 \\
\end{tabular} & 4 & 4 & 3 & 3 & 3 & \begin{tabular}{l|l}
3 & 3 \\
\end{tabular} & 4 & & \begin{tabular}{|l|l}
4 & \\
\end{tabular} & \begin{tabular}{l|l}
3 & 4 \\
\end{tabular} & \begin{tabular}{|l|l}
4 & 4 \\
\end{tabular} & & & \\
\hline & Jumlah & & 26 & & & & & & & 50 & & & & & & & & & & & & & & & \\
\hline & $\bar{X}$ peraspek & & 3,3333 & 33 & & & & & & 2628 & 20513 & & & & & & 0769 & & & +0 & 1538 & & & & \\
\hline & $\%$ per aspek & & 83 & & & & & & & 82 & & & & & & & J & & & $\mathrm{J}$ & & & & & \\
\hline
\end{tabular}

Berdasarkan Tabel 4 diketahui respon mahasiswa terhadap modul multimedia interaktif dengan rincian per aspek adalah aspek tampilan mendapatkan nilai 3,33 dan persentase kelayakan sebesar 83\% dengan kategori sangat baik (B), aspek isi/konten mendapatkan nilai 3,26 dan persentase kelayakan sebesar $82 \%$ dengan kategori sangat baik (SB), aspek bahasa mendapatkan nilai sebesar 3,30 dan persentase kelayakan sebesar 83\% dengan kategori sangat baik (SB), aspek media secara keseluruhan mendapatkan nilai 3,38 dan persentase kelayakan sebesar $85 \%$ dengan kategori sangat baik (SB).

\section{Hasil Akhir Pengembangan}

Produk akhir penelitian pengembangan ini berupa aplikasi modul berbasis multimedia interaktif dalam bentuk (.exe) dengan animasi pada prosedur kerja yang didesain menyerupai praktikum sebenarnya dan simulasi dari suatu rangkaian. Modul ini sepenuhnya dalam kendali pengguna karena dapat di-setting pada bagian simulasi proteus. Modul terdiri dari tiga bagian yaitu Tampilan awal, tampilan pembuka dan tampilan utama. 


\section{KESIMPULAN}

Berdasarkan hasil penelitian yang dilakukan diperoleh kesimpulan sebagai berikut:

1. Modul Paktikum Elektronika Dasar I Berbasis multimedia interaktif dikembangkan dengan prosedur pengembangan prosedural dengan memperhatikan siklus pengembangan yang meliputi (1) Analisis kebutuhan, (2) Perancangan modul (3) Pembuatan modul (4) Pengujian (5) Pengoperasian dan Pemeliharaan. Perangkat lunak yang digunakan adalah Adobe Flash Cs 6 dan Proteus 8.

2. Hasil pengujian diperoleh kualitas modul menurut ahli bahan ajar dengan kategori baik (B) dengan nilai 3,92 dan persentase keidealan 78\%, menurut ahli media dengan kategori baik (B) dengan nilai 3,71 dan persentase 73\%, dan menurut Dosen pengampu praktikum dengan kategori sangat baik (SB) dengan nilai 3,72 dan persentase keidealan 94\%. Hasil uji lapanagan terbatas dan uji lapangan luas diperoleh kualitas modul dengan kategori sangat baik (SB) dengan nilai pada uji terbatas 3,30 dan persentase keidealan $83 \%$ dan uji luas dengan nilai 3,32 dan persentase keidealan 83\%. Hasil secara kesuluruhan menunjukkan ratarata nilai 3,59 dan rata-rata persentase keidealan sebesar $83 \%$ maka kualitas modul dikategorikan sangat baik (SB).

\section{DAFTAR PUSTAKA}

Andi, Prastowo, 2014, Pengembangan Bahan Ajar Tematik, Prenada Media Group, Jakarta Arsyad Ashar, 2003, Media Pembelajaran, PT Raja Grafindo Persada, Jakarta

Chandra, NAriadie, dkk., 2012, Modul Proteus Profesional 7.5 ISIS digital Simulation, Fakultas Teknik, UNY, Yogyakarta

Damiri, DhamiJohar, Implementation Project Based Learnigon Local Area Network Training, International Journal of Basic and Aplied Science, dalam www.insikapub.com, diakses pada 02 Februari 2016

Daryanto, 2013, Menyusun Modul (Bahan ajar untuk Persiapan Guru dalam Mengajar), Gava Media, Yogyakarta

Nurtantio, Pulung dan Arry Maulana S, 2013, Kreasikan Animasimu Dengan Adobe FLASH dalam membuat Sistem multimedia Interaktif, CV. ANDI OFFSET, Yogyakarta 